\title{
Chemical and Physical Properties of Douglas Fir Bark Relevant to the Production of Container Plants
}

\author{
M. Gabriela Buamscha ${ }^{1}$ \\ Cooperative Forestry, U.S. Forest Service, P.O. Box 3623, Portland, \\ OR 97208-3623
}

\author{
James E. Altland ${ }^{2,5}$ \\ Department of Horticulture, Oregon State University, North Willamette \\ Research and Extension Center, 15210 NE Miley Road, Aurora, OR 97002 \\ Dan M. Sullivan ${ }^{3}$ \\ Crop and Soil Science Department, Oregon State University, 3017 ALS \\ Building, Corvallis, OR 97331
}

\author{
Donald A. Horneck ${ }^{3}$ \\ Crop and Soil Science Department, Oregon State University, P.O. Box 105, \\ Hermiston, OR 97838
}

James Cassidy ${ }^{\mathbf{4}}$

Crop and Soil Science Department, Oregon State University, 3017 ALS Building, Corvallis, OR 97331

Additional index words. Pseudotsuga menziesii, fresh bark, aged bark, nutrients, bark physical properties, water-holding capacity, particle size

\begin{abstract}
A 1-year survey on the chemical and physical properties of Douglas fir [Pseudotsuga menziesii (Mirbel) Franco] bark was conducted with the following objectives: 1) to document baseline chemical and physical properties of Douglas fir bark (DFB) that have relevance to production of container plants; 2) to determine the effect of DFB age on its chemical and physical properties; and 3) to document the consistency of those properties throughout the year. In June, August, October, and Dec. 2005, and February and May 2006, fresh and aged DFB samples were collected from two primary DFB suppliers (bark sources) for Oregon nurseries: source A offers a bark screened to $0.95 \mathrm{~cm}$ or less (fine) and source B screened to $2.2 \mathrm{~cm}$ or less (coarse). Samples were analyzed for pH, electrical conductivity (EC), essential plant macro- and micronutrients, bulk density, particle size distribution, and substrate moisture characteristic curves. Air space (AS), container capacity (CC), and solids were determined as a percent of container volume. Nonamended fresh and aged DFB contains appreciable extractable amounts of all measured plant macro- and micronutrients, except $\mathbf{N}$. In general, the aging process reduced $\mathrm{pH}$; and increased $\mathrm{EC}$, and extractability of phosphorous, calcium, magnesium, boron, iron, and aluminum. Uniformity of DFB chemical properties throughout the year was affected by bark source and less so by age. In terms of physical properties, aged DFB had lower AS and higher CC compared with fresh DFB. Average differences in AS and CC between fresh and aged DFB within a source were $8 \%$ or less. Similar to chemical properties, uniformity of DFB physical properties was more affected by bark source than age.
\end{abstract}

Container crops in the Pacific Northwest (PNW) are grown primarily in Douglas fir [Pseudotsuga menziesii (Mirbel) Franco]

Received for publication 2 Feb. 2007. Accepted for publication 14 Mar. 2007

We thank the Oregon Association of Nurseries for funding this research and Gilda Medina, Walter Briones, Vyacheslav Dobryk, Peng Yong, and Magdalena Zazirska for skillful technical assistance. ${ }^{1}$ Western Nursery Specialist as of 19 Mar. 2007.

${ }^{2}$ Assistant Professor.

${ }^{3}$ Associate Professor.

${ }^{4}$ Crop \& Soil Science Instructor/Faculty Research Assistant.

${ }^{5}$ To whom reprint requests should be addressed; e-mail james.altland@oregonstate.edu bark (DFB). Similar to Loblolly pine (Pinus taeda L.) bark in the southeast United States, DFB comprises the highest portion of most nursery substrates $(60 \%$ to $80 \%$ of the substrate mix, personal observation in the PNW). Douglas fir bark is often incorporated with peatmoss, sand, compost, pumice, or other materials. Despite its widespread use, little information is available on the chemical and physical properties of DFB as it pertains to use as a container substrate. Most literature on this subject refers to the chemical properties of soluble components extracted for pulpwood or other industrial chemical purposes (Bowyer et al., 2003; Harkin and Rowe, 1971).
Chemical properties of pine bark (based on water extractions) have been documented and summarized in a review by Ogden et al. (1987). Tucker (1995) reported for nonamended pine bark; low $\mathrm{pH}$ (3.4 to 4.5$)$, high phosphorous $\left(\mathrm{P} ; 11.5\right.$ to $\left.23 \mathrm{mg} \cdot \mathrm{L}^{-1}\right)$ and potassium $\left(\mathrm{K} ; 134\right.$ to $\left.215 \mathrm{mg} \cdot \mathrm{L}^{-1}\right)$; sufficient manganese $\left(\mathrm{Mn} ; 4.5\right.$ to $\left.15 \mathrm{mg} \cdot \mathrm{L}^{-1}\right)$ and copper $\left(\mathrm{Cu} ; 0.22\right.$ to $\left.0.50 \mathrm{mg} \cdot \mathrm{L}^{-1}\right)$; and low calcium $(\mathrm{Ca} ; 8.5 \%$ to $24 \%$ of cation exchange capacity [CEC]), magnesium ( $\mathrm{Mg} ; 4.5 \%$ to $6.2 \%$ of $\mathrm{CEC}$ ), and zinc ( $\mathrm{Zn} ; 1.8$ to 4.4 $\mathrm{mg} \cdot \mathrm{L}^{-1}$ ) when compared with established sufficiency ranges (Warncke, 1998). Niemiera (1992) reported pine bark alone provided $0.10 \mathrm{mg} \cdot \mathrm{L}^{-1} \mathrm{Cu}, 22.7 \mathrm{mg} \cdot \mathrm{L}^{-1}$ iron (Fe), $9.7 \mathrm{mg} \cdot \mathrm{L}^{-1} \mathrm{Mn}$, and $3.9 \mathrm{mg} \cdot \mathrm{L}^{-1} \mathrm{Zn}$, just slightly lower than bark amended with Micromax (Scotts Co., Marysville, OH) and Ironite (Ironite Products Co., Scottsdale, AZ).

Fresh and aged DFB are used commonly in Oregon container nurseries. Fresh bark refers to material sold soon after tree debarking, grinding, and screening to size; aged bark refers to material that goes through the same preparation process but also sits in undisturbed piles ( 7 to $12 \mathrm{~m}$ tall) for an average of 7 months before use. Container nurseries are equally divided in their preference for fresh and aged bark (Jack Hoeck, Rexius Bark, Eugene, OR, personal communication). Some of those preferring fresh DFB often claim it is more consistent from batch to batch than aged DFB. Skogholm cotoneaster (Cotoneaster dammeri C.K.Schneid 'Skogholm') grown in aged pine bark was larger than cotoneaster grown in fresh pine bark (Harrelson et al., 2004). The authors attributed the reduction in growth in fresh bark to differences in physical properties. Container capacity and available water in fresh pine bark were significantly lower than in aged bark, in particular at the beginning of the study. In the same study, pine bark age had no effect on substrate $\mathrm{pH}$ or electrical conductivity (EC).

Nutrient content of bark differs not only between species, but also with tree age, environmental factors, and growing site (Bollen, 1969). Bollen also stated that DFB has almost no plant nutrient value in terms of nitrogen $(\mathrm{N}), \mathrm{P}, \mathrm{K}, \mathrm{Ca}$, and $\mathrm{Mg}$. This statement is based on concentration of each nutrient on a dry matter basis. Buamscha and Altland (2005) contradict this notion in that they reported high levels of waterextractable $\mathrm{P}$ and sufficient levels of waterextractable K compared with established sufficiency ranges (Warncke, 1998; Yeager et al., 2000). Bollen (1969) also reported that bark of Douglas fir, ponderosa pine (Pinus ponderosa P. \& C. Lawson), and redwood [Sequoia sempervirens (Lamb ex D. Don) Endl] differ in $\mathrm{pH}$, carbon to nitrogen $(\mathrm{C} / \mathrm{N})$ ratio, and content of the mentioned nutrients. Considering the differences in chemical properties of DFB and other conifer barks, research conducted on pine bark with respect to nursery container nutrition cannot be assumed completely applicable to DFB. 
Physical properties of a substrate must also be considered. Container substrates are often developed or chosen by nursery growers based primarily on their perceived physical properties. Most research on the physical and hydraulic properties of container substrates has been done with peatmoss or pine bark. Milled pine bark needs a range of both fine and coarse particle sizes to be suitable as a container substrate; as a general rule, $70 \%$ to $80 \%$ of the particles should be within a range of 0.6 to $9.5 \mathrm{~mm}$ in diameter and the remaining particles less than $0.6 \mathrm{~mm}$ (Pokorny, 1979). After irrigation and drainage, pine bark-based substrates should have $10 \%$ to $30 \%$ air space (AS), $45 \%$ to $65 \%$ container capacity (CC), $25 \%$ to $35 \%$ available water, $25 \%$ to $35 \%$ unavailable water, and 0.19 to $0.70 \mathrm{~g} \cdot \mathrm{cm}^{-3}$ bulk density $\left(\mathrm{D}_{\mathrm{b}}\right)$ (Yeager et al., 2000). Most of the available water in a pine bark substrate is held at tensions less than $2.5 \mathrm{kPa}$, whereas water held at tensions greater than $10 \mathrm{kPa}$ is not readily available for plants (Ingram et al., 1993). In the PNW, substrates are compared with the aforementioned guidelines for pine bark.

Uniformity of DFB properties throughout the year has not been studied. Trees are harvested by lumber mills virtually yearround. Bark removal is easy during the spring when water flows readily through the xylem. However, during fall and winter, bark is more difficult to remove; thus, lumber mills scrape more wood off the tree in an effort to remove all the undesirable bark. Higher concentration of wood in bark supplies is one way that chemical and physical properties of bark may change throughout the year. Moisture can also impact the bark screening process; moisture causes small particles to stick to large particles, making the screening less precise.

The north Willamette Valley in Oregon receives $\approx 1.1 \mathrm{~m}$ precipitation annually, most of which occurs between November and March (Taylor, 2005). Consequently, time of the year relative to rainfall may affect particle size distribution and other properties of DFB (Scott Leavengood, Wood Products Extension Agent, Oregon State University, personal communication).

Douglas fir bark is widely accepted as an excellent substrate for container production among nursery producers, hence its widespread use in Oregon and other regions where Douglas fir constitutes a significant portion of the forest products industry. Despite its widespread use, little is known about DFB as it pertains to use as a container substrate. Therefore, the objectives of this study were: 1) to document baseline chemical and physical properties of DFB that have relevance to production of container plants; 2) to determine the effect of age on DFB chemical and physical properties; and 3) to document the consistency of those properties throughout the year.

\section{Materials and Methods}

Fresh and aged DFB samples were collected from two Oregon bark suppliers in
June, August, October, and Dec. 2005 as well as February and May 2006. The two companies are the primary sources of DFB for nursery growers in Oregon. They differ with respect to the particle size of the finished material, source A offering a finer screened bark at $0.95 \mathrm{~cm}$ or less (fine) and source B offering a coarser screened bark at $2.2 \mathrm{~cm}$ or less (coarse). At each visit, fresh bark samples were collected from a pile that was processed within the previous $48 \mathrm{~h}$; aged bark was collected from piles that had been stored at the processing site for an average of 7 months. The exact duration of the aging process at the time of sampling could not be determined. Fresh and aged bark occurs in single and separate piles at each of the bark suppliers. Each pile was roughly $5 \mathrm{~m}$ tall and $10 \mathrm{~m}$ wide, although pile size was never constant. At each collection date, three subsamples were randomly taken from each pile of differing screen size and bark age. Bark subsamples were collected from each pile by scraping away the surface $0.3 \mathrm{~m}$ of bark and collecting $0.019 \mathrm{~m}^{3}$ into a plastic bucket. Samples were stored in the sealed buckets and placed in a cooler $\left(1^{\circ} \mathrm{C}\right)$ until samples could be processed (all samples were processed within $2 \mathrm{~d}$ ).

A representative $0.004 \mathrm{~m}^{3}$ of each subsample was placed in a plastic bag and sent immediately to a laboratory: Samples were analyzed for $\mathrm{pH}, \mathrm{EC}$, ammonium $\left(\mathrm{NH}_{4}-\mathrm{N}\right)$, nitrate $\left(\mathrm{NO}_{3}-\mathrm{N}\right), \mathrm{P}, \mathrm{K}, \mathrm{Ca}, \mathrm{Mg}$, sulfate $\left(\mathrm{SO}_{4}^{-}-\right.$ $\mathrm{S})$, and aluminum (Al) using the Saturated Media Extract (SME) method with water as the extractant (Warncke, 1998) and modified by Gavlak et al. (2003). Boron (B), Fe, Mn, $\mathrm{Cu}$, and $\mathrm{Zn}$ were analyzed using a SME as well, but with diethylenetriaminepentaacetic acid (DTPA) as the extractant. Modifications by Gavlak et al. (2003) to the SME procedure involved soaking DFB in the extractant (either water or DTPA) for $24 \mathrm{~h}$ instead of $1 \mathrm{~h}$ recommended by Warncke (1998). Extracted solutions were analyzed for the mentioned elements, except N, by inductively coupled plasma-emission spectrometry (Thermo Jarrel Ash, Offenbach, Germany). Ammonium and $\mathrm{NO}_{3}-\mathrm{N}$ were analyzed colorimetrically using a Lachat Quick Chem 8000 (Lachat Instruments, Milwaukee, WI).

Each bark sample was analyzed for $\mathrm{D}_{\mathrm{b}}$ $\left(\mathrm{g} \cdot \mathrm{cm}^{-3}\right)$, percent AS, CC, and solids using an aluminum core $(7.6 \mathrm{~cm}$ tall and $7.6 \mathrm{~cm}$ diameter) packed with each substrate and attached to a North Carolina State University (NCSU) Porometer (Fonteno and Bilderback, 1993). Particle size distribution of each sample was determined with 14 sieves (19.0, $12.5,6.3,4.0,2.8,2.0,1.4,1.0,0.71,0.50$, $0.35,0.25,0.18$, and $0.11 \mathrm{~mm}$ ) plus a bottom pan (Bilderback et al., 1982). Sieves and pan were shaken for 5 min with a RX-29 Ro-Tap sieve shaker (278 oscillations min $^{-1}$, 150 taps $\min ^{-1}$; W.S. Tyler, Mentor, OH).

Substrate moisture characteristic curves expressed as volumetric water content at increasing tension were obtained for fresh and aged coarse $(2.2 \mathrm{~cm}$ or less screen size $)$ DFB collected from source B on May 2006.
Volumetric water content at complete saturation and after saturation and drainage for $1 \mathrm{~h}$ (CC) was obtained from an aluminum core $(3.8 \mathrm{~cm}$ tall and $7.6 \mathrm{~cm}$ diameter) attached to a NCSU Porometer. The same core was then placed in an apparatus described in Fonteno et al. (1981) and Milks et al. (1989) and modified as follows. The stem of a $600-\mathrm{mL}$ Pyrex Buchner filter funnel with fritted plate of medium porosity (VWR, Westchester, PA) was connected to a 1-L Erlenmeyer flask using plastic tubing ( 0.32 $\mathrm{cm}$ internal diameter). The Erlenmeyer flask was half-filled with water and served to apply tension by changing the head difference at the base of the fritted plate between 1 and $6.1 \mathrm{kPa}$.

Data were subjected to multivariate analysis of variance to determine the influence of bark age and source on chemical and physical properties. Coefficient of variance (CV) for each parameter was calculated to assess data consistency over time (SAS Institute, 1999).

\section{Results and Discussion}

Douglas fir bark chemical properties. Nonamended DFB chemical properties were compared with nutrient guidelines for greenhouse growth media analyzed with a SME (Warncke, 1998) and recommended substrate $\mathrm{pH}$ for container plant production (Yeager et al., 2000) (Table 1). Currently, there are no established macro- and micronutrient sufficiency ranges for container substrates analyzed with the SME method. Yeager et al. (2000) report nutrient guidelines for container substrates analyzed with the Virginia Tech Extraction Method, which cannot be compared with the SME results of our study.

Average bark $\mathrm{pH}$ ranged from 3.7 to 5.0 and thus considered low by most guidelines. Electrical conductivity was below or near the lower limit of recommended levels. Similar to pine bark (Ogden et al., 1987), DFBextractable $\mathrm{NH}_{4}-\mathrm{N}$ and $\mathrm{NO}_{3}-\mathrm{N}$ levels were low (1.3 and $0.3 \mathrm{mg} \cdot \mathrm{L}^{-1}$, respectively, averaged over bark type and collection date). Across all bark types, DFB had higher than recommended levels of extractable $\mathrm{P}$, sufficient to high $\mathrm{K}$ and $\mathrm{Cu}$, and sufficient $\mathrm{Mn}$. Extractable P levels in DFB were several times higher than the recommended range for a well-fertilized substrate (Warncke, 1998). Longevity of high P levels in a plant-available form is not certain. Yeager and Wright (1982) reported that high indigenous P levels in pine bark are rapidly leached from the substrate, reducing the potential for plant uptake. Unlike $\mathrm{P}$, potassium $(\mathrm{K})$ is not considered a pollutant (Handreck and Black, 2002). However, the high $\mathrm{K}$ levels extracted from DFB should be taken into account with nutrient programs. Extractable $\mathrm{Ca}, \mathrm{Mg}, \mathrm{SO}_{4}^{-}$, $\mathrm{B}$, and $\mathrm{Zn}$ were below recommended levels but still in notable quantities that should be accounted for in nutrient programs. Low $\mathrm{pH}$, $\mathrm{Ca}$, and $\mathrm{Mg}$ are of little consequence considering the industry-wide practice of preplant incorporation with dolomitic limestone (personal observation). Extractable Fe was high in aged bark and within recommended levels 
Table 1. Average chemical properties of fresh and aged Douglas fir bark from two bark sources and over six sampling dates $(\mathrm{n}=3)$.

\begin{tabular}{|c|c|c|c|c|c|c|c|c|c|c|c|c|c|c|c|}
\hline \multirow[b]{3}{*}{ Bark age } & \multirow[b]{3}{*}{ Date } & \multicolumn{9}{|c|}{ Water extraction $^{z}$} & \multicolumn{5}{|c|}{ DTPA extraction $^{2}$} \\
\hline & & $\overline{\mathrm{pH}}$ & $\mathrm{EC}^{\mathrm{y}}$ & $\mathrm{P}$ & $\mathrm{K}$ & $\mathrm{Ca}$ & $\mathrm{Mg}$ & $\mathrm{SO}_{4}$ & $\mathrm{Na}$ & Al & $\mathrm{B}$ & $\mathrm{Fe}$ & $\mathrm{Mn}$ & $\mathrm{Cu}$ & $\mathrm{Zn}$ \\
\hline & & & & & & & & & $\mathrm{mg} \cdot \mathrm{L}^{-1}$ & & & & & & \\
\hline \multirow[t]{6}{*}{$\overline{\text { Fresh }}$} & June 2005 & 4.4 & 267 & 14.8 & 101.0 & 19.9 & 9.4 & 12.1 & 10.9 & 13.2 & 0.20 & 28.6 & 10.7 & 0.36 & $\overline{2.4}$ \\
\hline & Aug. 2005 & 5.0 & 310 & 19.2 & 110.0 & 20.0 & 9.3 & 15.6 & 12.3 & 9.4 & 0.19 & 23.2 & 11.2 & 0.34 & 2.2 \\
\hline & Oct. 2005 & 4.2 & 293 & 13.8 & 97.3 & 20.9 & 9.6 & 18.0 & 15.8 & 9.4 & 0.27 & 22.7 & 9.3 & 0.46 & 2.3 \\
\hline & Dec. 2005 & 4.0 & 257 & 8.8 & 77.2 & 17.3 & 7.3 & 11.1 & 16.2 & 7.8 & 0.27 & 21.7 & 9.0 & 0.41 & 2.3 \\
\hline & Feb. 2006 & 4.2 & 235 & 12.2 & 95.9 & 26.7 & 11.0 & 10.4 & 10.4 & 10.4 & 0.25 & 28.6 & 8.1 & 0.45 & 2.2 \\
\hline & May 2006 & 4.5 & 219 & 10.5 & 78.4 & 20.4 & 8.1 & 13.0 & 12.3 & 9.7 & 0.23 & 30.6 & 12.1 & 0.47 & 3.6 \\
\hline \multirow[t]{6}{*}{ Aged } & June 2005 & 3.7 & 466 & 28.0 & 110.3 & 38.7 & 28.3 & 13.7 & 9.7 & 51.5 & 0.38 & 63.1 & 8.5 & 0.34 & 2.4 \\
\hline & Aug. 2005 & 4.4 & 264 & 10.3 & 78.8 & 21.5 & 14.6 & 11.2 & 12.6 & 10.4 & 0.37 & 84.6 & 7.9 & 0.30 & 2.6 \\
\hline & Oct. 2005 & 3.7 & 680 & 26.5 & 162.0 & 71.2 & 44.4 & 20.5 & 15.1 & 32.4 & 0.56 & 92.4 & 13.0 & 0.34 & 2.3 \\
\hline & Dec. 2005 & 4.2 & 386 & 18.1 & 117.6 & 38.7 & 21.7 & 13.1 & 14.3 & 15.9 & 0.51 & 77.2 & 11.6 & 0.43 & 3.2 \\
\hline & Feb. 2006 & 4.0 & 328 & 20.5 & 120.1 & 36.2 & 19.9 & 9.8 & 8.6 & 18.6 & 0.45 & 61.4 & 8.4 & 0.47 & 2.8 \\
\hline & May 2006 & 3.8 & 406 & 21.8 & 130.8 & 37.8 & 21.3 & 17.6 & 19.0 & 17.1 & 0.41 & 63.6 & 9.1 & 0.45 & 3.1 \\
\hline \multicolumn{2}{|c|}{ Recommended ranges } & $5-6^{x}$ & $480-1280^{w}$ & $3-5^{w}$ & $60-149^{w}$ & $80-199^{w}$ & $30-69^{w}$ & $30-150^{w}$ & $0-40^{w}$ & - & $0.7-2.5^{\mathrm{w}}$ & $15-40^{w}$ & $5-30^{w}$ & $0-0.35^{\mathrm{v}}$ & $5-30^{w}$ \\
\hline \multicolumn{2}{|c|}{ Sources of variation } & & & & & & & $\operatorname{Pr}>\mathrm{F}$ & & & & & & & \\
\hline \multicolumn{2}{|c|}{ Bark age (B) } & 0.0257 & 0.0443 & 0.0779 & 0.1309 & 0.0319 & 0.0133 & 0.4397 & 0.7762 & 0.0451 & $<.0001$ & 0.0008 & 0.8618 & 0.2544 & 0.3042 \\
\hline \multicolumn{2}{|c|}{ Bark source $(\mathrm{S})$} & 0.4475 & 0.4052 & 0.9026 & 0.1800 & 0.5614 & 0.3568 & 0.7068 & 0.2800 & 0.1089 & 0.1369 & 0.6817 & 0.5619 & 0.4280 & 0.0857 \\
\hline \multicolumn{2}{|l|}{$\mathrm{S} * \mathrm{~B}$} & 0.1644 & 0.8855 & 0.5939 & 0.7189 & 0.7101 & 0.5448 & 0.9007 & 0.2955 & 0.1108 & 0.1471 & 0.2913 & 0.6846 & 0.6110 & 0.2461 \\
\hline \multicolumn{2}{|l|}{ Date (D) } & 0.4851 & 0.7436 & 0.7005 & 0.9591 & 0.7262 & 0.6787 & 0.5445 & 0.0132 & 0.4129 & 0.6252 & 0.9536 & 0.7375 & 0.3605 & 0.6601 \\
\hline \multicolumn{2}{|l|}{$B * D$} & 0.1194 & 0.0434 & 0.3820 & 0.0519 & 0.0104 & 0.0498 & 0.4821 & 0.8591 & 0.0125 & 0.8308 & 0.5279 & 0.4392 & 0.7313 & 0.4156 \\
\hline \multicolumn{2}{|l|}{$S * D$} & 0.0387 & 0.0354 & 0.6516 & 0.0191 & 0.0184 & 0.0796 & 0.0932 & 0.7575 & 0.0866 & 0.5405 & 0.2019 & 0.5948 & 0.3664 & 0.1231 \\
\hline \multicolumn{2}{|l|}{$B * S * D$} & 0.5080 & 0.5263 & 0.0137 & 0.5463 & 0.8692 & 0.5304 & 0.2995 & 0.0103 & 0.8190 & 0.0579 & 0.0004 & 0.0010 & 0.1071 & 0.6775 \\
\hline
\end{tabular}

${ }^{\mathrm{z}}$ Water and DTPA extractions using the Saturated Media Extract (SME) method (Gavlak et al., 2003; Warncke, 1998).

${ }^{\mathrm{y}}$ Electrical conductivity $(\mathrm{EC})$ in $\mathrm{ppm}=(\mathrm{mmhos} / \mathrm{cm}) \times 640$.

${ }^{x}$ Yeager et al., 2000.

${ }^{\mathrm{w}}$ General guidelines for substrates analyzed by the SME method (Warncke, 1998).

${ }^{\mathrm{v}}$ Guidelines provided by Brookside Laboratories (New Knoxville, $\mathrm{OH}$ ).

DTPA $=$ diethylenetriaminepentaacetic acid.

in fresh bark. Sodium in all bark samples was sufficiently low. Micronutrients in DFB seem to be sufficient for production of some container crops. Buamscha et al. (2007) demonstrated that DFB alone provided sufficient micronutrients for annual vinca [Catharanthus roseus (L.) G. Don 'Peppermint Cooler'] grown over a 2-month period at pH 4.7 to 5.7. Similarly, pine bark amended with $25 \%$ to $50 \%$ composted hardwood bark provided sufficient $\mathrm{B}, \mathrm{Fe}, \mathrm{Mn}$, and $\mathrm{Zn}$ for geranium (Pelargonium $\times$ hortorum L.) growth (Svenson and Witte, 1992). These data contradict Bollen's (1969) assessment that DFB has virtually no nutrient value.

The age of DFB influenced $\mathrm{pH}, \mathrm{EC}$, and soluble $\mathrm{P}(P=0.0779), \mathrm{Ca}, \mathrm{Mg}, \mathrm{B}, \mathrm{Fe}$, and Al. Across both sources and collection dates, aged DFB had lower $\mathrm{pH}$ than the fresh material; however, the interaction between collection date and bark source indicates that this general trend is not consistently true at each date. Bark $\mathrm{pH}$ was negatively correlated to $\mathrm{EC}$, and extractable $\mathrm{P}, \mathrm{Ca}, \mathrm{Mg}, \mathrm{B}$, and $\mathrm{Fe}$ $(\mathrm{r}<-0.339$ across all parameters). Aged DFB had also higher levels of EC, P, Ca, Mg, B, and $\mathrm{Fe}$ than did fresh bark. In mineral soils, decreasing $\mathrm{pH}$ (below 7) results in increasing availability of $\mathrm{P}$ and other micronutrients. It is possible that organic acids released by decomposition of aged DFB reduced $\mathrm{pH}$, which increased availability of $\mathrm{P}, \mathrm{Ca}, \mathrm{B}$, and $\mathrm{Fe}$. Another possibility is that cations released from decomposition of aged DFB displaced $\mathrm{H}^{+}$ions on cation exchange sites, thus depressing $\mathrm{pH}$. Lower $\mathrm{pH}$ and increased salt levels are associated with aged DFB, although it is not clear which causes the other. Harrelson et al. (2004) did not observe an effect of pine bark age on substrate $\mathrm{pH}$, and Cobb and Keever (1984) reported higher $\mathrm{pH}$ in aged pine bark compared with fresh bark.

Date of sampling influenced most measured chemical parameters by interacting with bark age or bark source (with the exception of $\mathrm{SO}_{4}^{-}, \mathrm{Cu}$, and $\mathrm{Zn}$ ). Coefficients of variation (calculated as $\sigma / \mu$ ) provided a measure of data consistency over time (Table 2). Within both fresh and aged bark, nutritional parameters of source B (coarse) had lower CV than source A (fine) with few exceptions. Conversely, within source A, fresh bark had lower CV in 11 of the 14 measured parameters; in source $\mathrm{B}, \mathrm{CV}$ were lower in seven parameters each for fresh and aged bark. Considering the primary difference in bark sources is the screening size $(0.95 \mathrm{~cm}$ for source A and $2.2 \mathrm{~cm}$ for source B), this implies that chemical properties of DFB might be more uniform or consistent throughout the year in coarser bark grades.

Table 2. Coefficients of variation over 1 year for the chemical and physical properties of Douglas fir bark from two bark sources and two bark ages $(n=18)$.

\begin{tabular}{|c|c|c|c|c|}
\hline \multirow[b]{2}{*}{ Chemical properties ${ }^{\mathrm{y}}$} & \multicolumn{2}{|c|}{ Source A (fine) ${ }^{z}$} & \multicolumn{2}{|c|}{ Source B (coarse) } \\
\hline & Fresh bark & Aged bark & Fresh bark & Aged bark \\
\hline$\overline{\mathrm{pH}}$ & 12 & 13 & 9 & 9 \\
\hline $\mathrm{EC}$ & 33 & 70 & 35 & 28 \\
\hline $\mathrm{P}$ & 50 & 58 & 45 & 45 \\
\hline $\mathrm{K}$ & 25 & 57 & 31 & 27 \\
\hline $\mathrm{Ca}$ & 51 & 79 & 45 & 32 \\
\hline $\mathrm{Mg}$ & 49 & 87 & 49 & 37 \\
\hline $\mathrm{SO}_{4}$ & 31 & 75 & 22 & 22 \\
\hline $\mathrm{Na}$ & 32 & 80 & 22 & 32 \\
\hline B & 28 & 33 & 16 & 23 \\
\hline $\mathrm{Fe}$ & 39 & 25 & 31 & 40 \\
\hline Mn & 41 & 35 & 16 & 23 \\
\hline $\mathrm{Cu}$ & 23 & 32 & 24 & 31 \\
\hline $\mathrm{Zn}$ & 67 & 33 & 17 & 29 \\
\hline $\mathrm{Al}$ & 28 & 57 & 29 & 45 \\
\hline \multicolumn{5}{|l|}{ Physical properties ${ }^{\mathrm{x}}$} \\
\hline AS & 8 & 14 & 12 & 12 \\
\hline $\mathrm{CC}$ & 9 & 13 & 20 & 14 \\
\hline Solids & 13 & 12 & 16 & 14 \\
\hline $\mathrm{D}_{\mathrm{b}}$ & 7 & 9 & 15 & 8 \\
\hline
\end{tabular}

${ }^{\mathrm{z}}$ Bark from source A and B were screened to $0.95 \mathrm{~cm}$ and $2.2 \mathrm{~cm}$, respectively.

${ }^{y}$ Electrical conductivity (EC), pH, P, K, Ca, $\mathrm{Mg}, \mathrm{SO}_{4}, \mathrm{Na}, \mathrm{B}, \mathrm{Fe}, \mathrm{Mn}, \mathrm{Cu}, \mathrm{Zn}$, and $\mathrm{Al}$ analyzed with a Saturated Media Extract (SME) (Gavlak et al., 2003; Warncke, 1998).

${ }^{x}$ Air space (AS), container capacity (CC), solids, and bulk density $\left(\mathrm{D}_{\mathrm{b}}\right)$ determined with a North Carolina State University Porometer (Fonteno and Bilderback, 1993). 
Bark age was less important in terms of consistency than the source from which it was collected.

No documented Al testing exists for soilless substrates such as tree bark, which is possibly the result of the general agreement that organic soils and soilless substrate contain low amounts of Al (Lucas and Davis, 1961; Yeager and Barrett, 1985). Significant amounts of $\mathrm{Al}$ were extracted in DFB throughout the survey $\left(7.8\right.$ to $51.5 \mathrm{mg} \cdot \mathrm{L}^{-1}$ on average), which among other things could impact bloom color of hydrangea [(Hydrangea macrophylla (Thunb.) Ser.] (Blom and Piott, 1992). Aged DFB had higher waterextractable Al than did fresh bark.

Douglas fir bark physical properties. Nonamended DFB has high AS, low CC, adequate solids, and low $\mathrm{D}_{\mathrm{b}}$ (Table 3 ) compared with guidelines developed for pine bark in the southeastern United States (Yeager et al., 2000). Some nursery managers believe PNW substrates, particularly those used in Oregon, must have higher AS and lower CC compared with what is recommended in the southeast United States to compensate for the typically higher precipitation rates during the dormant winter season. Lack of drainage during the winter, when plants are transpiring little or no water through foliage, coupled with high precipitation rates, has caused root rot problems with many species (personal observation).
Air space, $\mathrm{CC}$, and solids were analyzed collectively with multivariate analysis of variance as a result of inherent correlations between each parameter. Collectively, these parameters were affected by an interaction among bark age, bark source, and date of collection. Air space was lower and $\mathrm{CC}$ higher in aged compared with fresh DFB. Average differences in AS and CC between fresh and aged DFB within a source were $8 \%$ or less but may be different enough to impact plant growth. Harrelson et al. (2004) reported larger differences in physical properties between fresh and aged pine bark right after potting; CC was $61 \%$ for aged and $49 \%$ for fresh, whereas available water was $26 \%$ for aged and $10 \%$ for fresh bark. In their study, Skogholm cotoneaster grew larger in aged compared with fresh pine bark, and the authors attributed this response to the aforementioned differences in physical properties. Not surprising, coarser DFB from source B generally had higher AS and lower CC than finer DFB from source A. Differences in physical properties were more pronounced between bark sources than bark age.

Sampling date influenced physical parameters. Each parameter fluctuated slightly over time with no discernible pattern in relation to time of year. An attempt was made to trace bark supplies back to the lumber yard and further back to the forest from which the trees originated to better understand how time of

Table 3. Douglas fir bark average air space (AS), container capacity $(C C)$, solids, and bulk density $\left(\mathrm{D}_{\mathrm{b}}\right)^{\mathrm{z}}$ resulting from two bark sources, two bark ages, and five sampling dates $(n=3)$.

\begin{tabular}{|c|c|c|c|c|c|c|}
\hline $\begin{array}{l}\text { Bark } \\
\text { source }^{y}\end{array}$ & $\begin{array}{c}\text { Bark } \\
\text { age }\end{array}$ & Date & AS & $\begin{array}{c}\mathrm{CC} \\
-(\%)\end{array}$ & Solids & $\begin{array}{c}\mathrm{D}_{\mathrm{b}} \\
\left(\mathrm{g} \cdot \mathrm{cm}^{-3}\right)\end{array}$ \\
\hline Source A & Fresh & June 2005 & 42 & 42 & 16 & 0.16 \\
\hline (fine) & & Oct. 2005 & 40 & 38 & 22 & 0.18 \\
\hline & & Dec. 2005 & 40 & 42 & 18 & 0.18 \\
\hline & & Feb. 2005 & 34 & 48 & 18 & 0.17 \\
\hline & & May 2006 & 39 & 40 & 20 & 0.17 \\
\hline & Aged & June 2005 & 38 & 45 & 17 & 0.17 \\
\hline & & Oct. 2005 & 42 & 40 & 18 & 0.17 \\
\hline & & Dec. 2005 & 32 & 52 & 16 & 0.16 \\
\hline & & Feb. 2005 & 31 & 55 & 14 & 0.16 \\
\hline & & May 2006 & 36 & 47 & 18 & 0.20 \\
\hline Source B & Fresh & June 2005 & 51 & 28 & 21 & 0.21 \\
\hline (coarse) & & Oct. 2005 & 48 & 32 & 20 & 0.17 \\
\hline & & Dec. 2005 & 54 & 29 & 16 & 0.14 \\
\hline & & Feb. 2005 & 42 & 43 & 15 & 0.14 \\
\hline & & Мay-06 & 51 & 30 & 20 & 0.16 \\
\hline & Aged & June 2005 & 50 & 32 & 18 & 0.18 \\
\hline & & Oct. 2005 & 41 & 42 & 18 & 0.18 \\
\hline & & Dec. 2005 & 41 & 45 & 13 & 0.17 \\
\hline & & Feb. 2005 & 39 & 44 & 17 & 0.17 \\
\hline & & May 2006 & 45 & 38 & 17 & 0.17 \\
\hline Recomme & & & $10-30$ & $45-65$ & $15-50$ & $0.19-0.70$ \\
\hline Sources o & & & & $\operatorname{Pr}>F$ & & $\operatorname{Pr}>F$ \\
\hline Bark sour & & & & 0.0001 & & 0.7133 \\
\hline Bark age & & & & 0.0001 & & 0.0902 \\
\hline$S * B$ & & & & 0.7316 & & 0.5870 \\
\hline Date (D) & & & & 0.0001 & & 0.5650 \\
\hline$S^{*} \mathrm{D}$ & & & & 0.0135 & & 0.4609 \\
\hline$B * D$ & & & & 0.0111 & & 0.8173 \\
\hline $\mathrm{S} * \mathrm{~B} * \mathrm{D}$ & & & & 0.0042 & & 0.0088 \\
\hline
\end{tabular}

${ }^{\mathrm{z}}$ All parameters determined with a North Carolina State University Porometer (Fonteno and Bilderback, 1993).

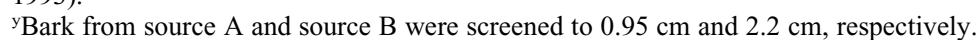

${ }^{\mathrm{x}}$ Recommended physical properties for pine bark substrates (Yeager et al., 2000).

year affects bark properties. However, as a result of safety and privacy concerns, lumber mills contacted were unwilling to accommodate us. Consistency of DFB physical properties over time were estimated using coefficients of variation (Table 2). Container capacity, $\mathrm{D}_{\mathrm{b}}$, and solids were more consistent (lower CV) over time from source A (fine) compared with source B (coarse).

Bulk density was influenced by an interaction among bark age, bark source, and collection date, although measured differences were minor (Table 3 ). Container weight is a function of the substrate's $D_{b}$ and CC. Heavier containers will be less likely to blow over in the nursery, but their shipping cost will be higher. In addition, some insecticide applications use rates based on substrate $D_{b}$ (for example, bifenthrin [Talstar, FMC Corporation, Philadelphia, PA]). Our data show that DFB age or source (particle size) did not have an economically important effect on $\mathrm{D}_{\mathrm{b}}$.

Analysis of variance indicated that particle size distribution was affected by an interaction among all variables (bark age, source, and date of collection) (Table 4). Although differences between fresh and aged bark were significant, measurable differences were negligible. Casual scanning of the table reveals some inconsistencies in the $6.3-\mathrm{mm}$ screen between fresh and aged bark. Bark of two different screen sizes had different particle size distributions, as would be expected. Source B (coarse) generally had greater mass in screens greater than $4 \mathrm{~mm}$, whereas source A (fine) had greater mass in screens 0.25 to $2.8 \mathrm{~mm}$. For pine bark, Pokorny (1979) recommended a substrate contain $70 \%$ to $80 \%$ coarse particles $(0.6$ to $9.5 \mathrm{~mm}$ in diameter) and $20 \%$ to $30 \%$ fine particles (less than $0.6 \mathrm{~mm}$ ). Source A (fine) fell within these guidelines, whereas source B (coarse) had more coarse particles and fewer fine particles than recommended. As mentioned previously, coarser substrates are likely beneficial for wet winters characteristic of the PNW.

A single sample of fresh and aged DFB from source B (coarse) was analyzed for its substrate moisture characteristic curve (Fig. 1); consequently, curves cannot be compared statistically. Nevertheless, they provide an insight on the moisture-releasing properties of DFB. Container capacity for fresh and aged bark were $36 \%$ and $44 \%$, respectively. Easily available water (EAW), the amount of moisture released between 1 and $5 \mathrm{kPa}$ (De Boodt and Verdonck, 1972) was 69\% and $86 \%$ of the total available water (CC) for fresh and aged bark, respectively. De Boodt and Verdonck (1972) suggest that optimal range for EAW is $75 \%$ to $90 \%$ of total available water. Unavailable water has been defined as that which is still held by a substrate at pressure higher than $10 \mathrm{kPa}$ by Ingram et al. (1993) or $1500 \mathrm{kPa}$ by De Boodt and Verdonck (1972). There is no agreement on the exact pressure at which water is unavailable to plants in a soilless substrate. Our curves were ended at $6.1 \mathrm{kPa}$, at which there was $14 \%$ and $11 \%$ of CC still held by 


\begin{tabular}{|c|c|c|c|c|c|c|c|c|c|c|c|c|c|c|c|c|}
\hline \multirow[b]{4}{*}{ Sieve size $(\mathrm{mm})$} & \multicolumn{8}{|c|}{ Source A (fine) $)^{z}$} & \multicolumn{8}{|c|}{ Source B (coarse) } \\
\hline & \multicolumn{2}{|c|}{ Oct. 2005} & \multicolumn{2}{|c|}{ Dec. 2005} & \multicolumn{2}{|c|}{ Feb. 2006} & \multicolumn{2}{|c|}{ May 2006} & \multicolumn{2}{|c|}{ Oct. 2005} & \multicolumn{2}{|c|}{ Dec. 2005} & \multicolumn{2}{|c|}{ Feb. 2006} & \multicolumn{2}{|c|}{ May 2006} \\
\hline & $\mathrm{F}^{\mathrm{y}}$ & $\mathrm{A}$ & $\mathrm{F}$ & $\mathrm{A}$ & $\mathrm{F}$ & $\mathrm{A}$ & $\mathrm{F}$ & $\mathrm{A}$ & $\mathrm{F}$ & A & $\mathrm{F}$ & $\mathrm{A}$ & $\mathrm{F}$ & $\mathrm{A}$ & $\mathrm{F}$ & $\mathrm{A}$ \\
\hline & & & & & & & & & & & & & & & & \\
\hline 19.00 & 0 & 1 & 0 & 0 & 0 & 0 & 0 & 0 & 0 & 0 & 0 & 0 & 0 & 0 & 0 & 0 \\
\hline 12.50 & 0 & 1 & 0 & 0 & 0 & 0 & 0 & 1 & 2 & 5 & 1 & 1 & 1 & 0 & 0 & 0 \\
\hline 6.30 & 7 & 2 & 6 & 1 & 5 & 5 & 7 & 4 & 22 & 30 & 24 & 34 & 24 & 18 & 29 & 29 \\
\hline 4.00 & 19 & 16 & 14 & 15 & 15 & 15 & 16 & 13 & 17 & 17 & 19 & 23 & 20 & 18 & 22 & 21 \\
\hline 2.80 & 16 & 17 & 12 & 18 & 15 & 17 & 14 & 14 & 11 & 10 & 12 & 12 & 12 & 15 & 12 & 13 \\
\hline 2.00 & 12 & 12 & 10 & 13 & 12 & 13 & 11 & 11 & 9 & 7 & 9 & 7 & 9 & 12 & 8 & 8 \\
\hline 1.40 & 9 & 9 & 8 & 9 & 10 & 11 & 9 & 9 & 6 & 5 & 6 & 4 & 7 & 9 & 5 & 6 \\
\hline 1.00 & 7 & 7 & 7 & 7 & 8 & 9 & 7 & 8 & 5 & 5 & 5 & 3 & 5 & 6 & 4 & 5 \\
\hline 0.71 & 7 & 7 & 7 & 8 & 7 & 9 & 6 & 7 & 5 & 4 & 5 & 3 & 4 & 5 & 3 & 4 \\
\hline 0.50 & 6 & 8 & 9 & 9 & 8 & 8 & 7 & 8 & 5 & 4 & 5 & 3 & 5 & 5 & 4 & 4 \\
\hline 0.35 & 5 & 7 & 8 & 8 & 6 & 5 & 6 & 6 & 5 & 3 & 4 & 3 & 4 & 4 & 3 & 3 \\
\hline 0.25 & 4 & 5 & 7 & 5 & 6 & 3 & 6 & 6 & 4 & 3 & 3 & 2 & 4 & 3 & 3 & 2 \\
\hline 0.18 & 3 & 4 & 4 & 3 & 3 & 2 & 4 & 5 & 3 & 3 & 3 & 2 & 3 & 2 & 3 & 2 \\
\hline 0.11 & 3 & 3 & 4 & 2 & 2 & 1 & 3 & 5 & 3 & 2 & 2 & 1 & 2 & 1 & 2 & 2 \\
\hline Pan & 2 & 2 & 2 & 2 & 2 & 2 & 2 & 5 & 2 & 1 & 2 & 1 & 1 & 2 & 2 & 2 \\
\hline Source of variation & & & & & & & & & & & & & & & & \\
\hline Bark source $(\mathrm{S})$ & & & & & & & & & & & & & & & & \\
\hline Bark age (A) & & & & & & & & & & & & & & & & \\
\hline $\mathrm{S} * \mathrm{~A}$ & & & & & & & & & & & & & & & & \\
\hline Date (D) & & & & & & & & & & & & & & & & \\
\hline $\mathrm{S} * \mathrm{D}$ & & & & & & & & & & & & & & & & \\
\hline$A^{*} \mathrm{D}$ & & & & & & & & & & & & & & & & \\
\hline $\mathrm{A} * \mathrm{~S} * \mathrm{D}$ & & & & & & & & & & & & & & & & \\
\hline
\end{tabular}

${ }^{2}$ Bark from source A and source B were screened to $0.95 \mathrm{~cm}$ and $2.2 \mathrm{~cm}$, respectively.

${ }^{\mathrm{y}} \mathrm{F}$ and $\mathrm{A}$ refer to fresh and aged Douglas fir bark, respectively.

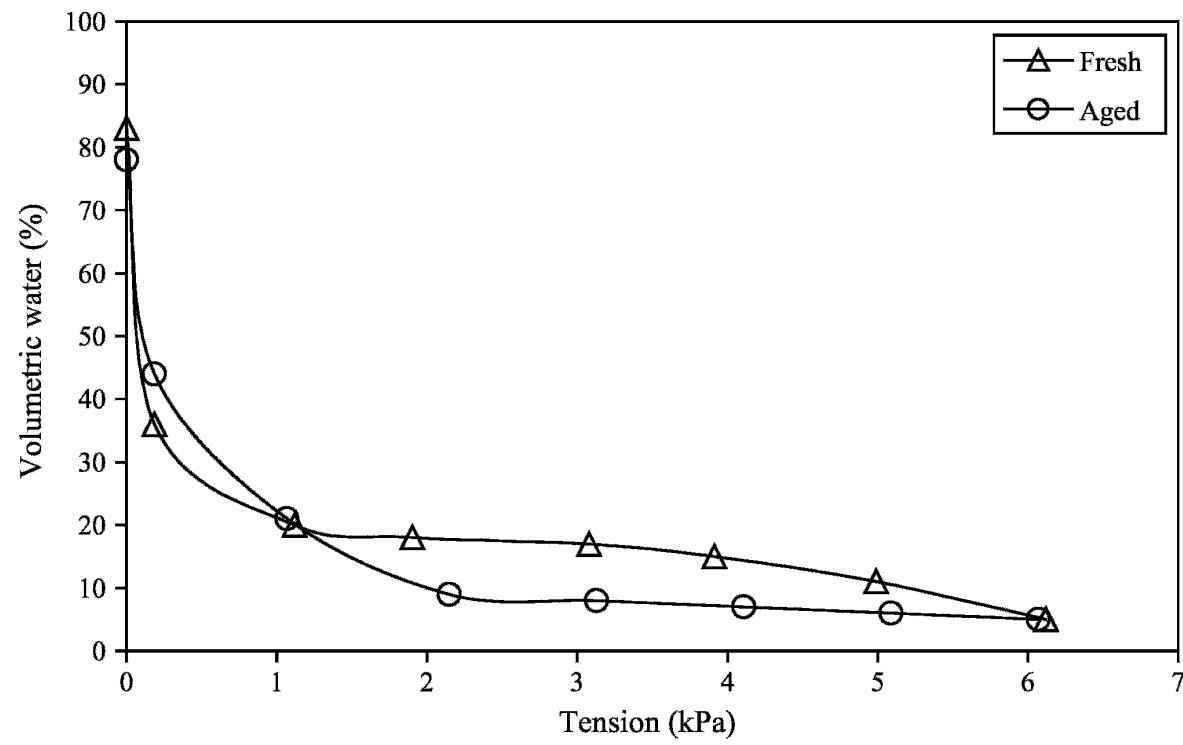

Fig. 1. Substrate moisture characteristic curves for coarse fresh and aged Douglas fir bark collected on May 2006. Curves obtained with a North Carolina State University Porometer (Fonteno and Bilderback, 1993) and B Buchner filter funnel (modified from Fonteno et al., 1981, and Milks et al., 1989). Douglas fir bark was initially passed through a $2.2-\mathrm{cm}$ screen (source B) when processed by the supplier.

fresh and aged DFB, respectively. Moisture characteristic curves generated for DFB appear similar in shape as those for pine bark reported by Tilt et al. (1987). However, curves generated for pine bark appear to become asymptotic with $30 \%$ to $35 \%$ moisture still retained in the bark compared with just $10 \%$ for DFB. This suggests a greater percent of CC is available for plant uptake in DFB compared with pine bark.

In summary, nonamended fresh and aged DFB contains appreciable amounts of measured plant macro- and micronutrients, except for $\mathrm{N}$ (data not shown). In general, the aging process reduced $\mathrm{pH}$ and increased the extractability of $\mathrm{P}, \mathrm{Ca}, \mathrm{Mg}, \mathrm{B}, \mathrm{Fe}$, and $\mathrm{Al}$. Consistency of DFB chemical properties throughout the year depended more on bark source than bark age; source B (coarse) was most consistent. Aged DFB had lower AS and higher CC. Similar to chemical data, (except for AS) was most influenced by source and not by age; source A (fine) had more consistent physical properties throughout the year. These findings do not support uniformity of DFB physical properties the belief of some Oregon nursery growers that fresh DFB has more consistent properties than aged DFB.

\section{Literature Cited}

Bilderback, T.E., W.C. Fonteno, and D.R. Johnson. 1982. Physical properties of media composed of peanut hulls, pine bark, and peatmoss and their effects on Azalea growth. J. Amer. Soc. Hort. Sci. 107:522-525.

Blom, T.J. and B.D. Piott. 1992. Florists' hydrangea blueing with aluminum sulfate applications during forcing. HortScience 27: 1084-1087.

Bollen, W.B. 1969. Properties of tree barks in relation to their agricultural utilization. USDA For. Serv. Res. Paper PNW 77.

Bowyer, J.L., R. Shmulsky, and J.G. Haygreen. 2003. Forest products and wood science: An introduction. 4th ed. Iowa State Press, Ames, IA.

Buamscha, G. and J. Altland. 2005. Pumice and the Oregon nursery industry. Digger 49:18 27.

Buamscha, M.G., J.E. Altland, D.M. Sullivan, and D.A. Horneck. 2007. Micronutrient availability in fresh and aged Douglas fir bark. HortScience 42:152-156.

Cobb, G.S. and G.J. Keever. 1984. Effects of supplemental $\mathrm{N}$ on plant growth in fresh and aged pine bark. HortScience 19:127-129.

De Boodt, M. and O. Verdonck. 1972. The physical properties of substrates in horticulture. Acta Hort. 26:37-44.

Fonteno, W.C. and T.E. Bilderback. 1993. Impact of hydrogel on physical properties of coarsestructured horticultural substrates. J. Amer. Soc. Hort. Sci. 118:217-222.

Fonteno, W.C., D.K. Cassel, and R.A. Larson 1981. Physical properties of three container media and their effect on Poinsettia growth. J. Amer. Soc. Hort. Sci. 106:736-741. 
Gavlak, R., D. Horneck, R. Miller, and J. KotubyAmacher. 2003. Soil, plant, and water reference methods for the Western region. 2nd ed. WCC103 Publication, Fort Collins, CO.

Handreck, K. and N. Black. 2002. Growing media for ornamental plants and turf. Univ. of New South Wales Press Ltd., Sydney.

Harkin, J.M. and J.W. Rowe. 1971. Bark and its possible uses. USDA. For. Serv. For. Prod. Lab. Madison, Wis. Res. Note FPL-0.91. 9 Mar. 2005. <http://www.fpl.fs.fed.us/documnts/fplrn/ fplrn091.pdf $>$.

Harrelson, T., S.L. Warren, and T. Bilderback. 2004. How do you manage aged versus fresh pine bark? Proc. Southern. Nurs. Assoc. Res. Conf. 49:63-66.

Ingram, D.L., R.W. Henley, and T.H. Yeager. 1993. Growth media for container grown plants Florida Coop. Ext. Serv. Univ. of Florida. Bulletin 24.

Lucas, R.E. and J.F. Davis. 1961. Relationships between $\mathrm{pH}$ values of organic soils and availabilities of 12 plant nutrients. Soil Sci. 92:177-182.

Milks, R.R., W.C. Fonteno, and R.A. Larson. 1989 Hydrology of horticultural substrates: I. Mathematical models for moisture characteristics of horticultural container media. J. Amer. Soc. Hort. Sci. 114:48-52.

Niemiera, A.X. 1992. Micronutrient supply from pine bark and micronutrient fertilizers. HortScience 27:272.

Ogden, R.J., F.A. Pokorny, H.A. Mills, and M.G. Dunavent. 1987. Elemental status of pine barkbased potting media. Hort. Rev. (Amer. Soc. Hort. Sci.) 9:103-131.

Pokorny, F.A. 1979. Pine bark container media-An overview. Proc. Inter. Plant Prop. Soc. 29:484-495.

SAS Institute. 1999. SAS user's guide and SAS statistical procedures. Version 8. SAS Inst., Cary, NC.

Svenson, S.E. and W.T. Witte. 1992. Ca, Mg, and micronutrient nutrition and growth of pelargonium in pine bark amended with composted hardwood bark. J. Environ. Hort. 10:125-129.

Taylor, G. 2005. Climatological data for Oregon agricultural regions. Oregon climate service. Oregon State University. 26 Sept. 2006. http:// www.ocs.oregonstate.edu/index.html.

Tilt, K.M., T.E. Bilderback, and W.C. Fonteno. 1987. Particle size and container size effects on growth of three ornamental species. J. Amer. Soc. Hort. Sci. 112:981-984.

Tucker, M.R. 1995. Chemical characteristics for pine bark. Media notes for North Carolina growers. North Carolina Dept. of Agric. and Consumer Serv. 3 Mar. 2004. http://www. ncagr.com/agronomi/pinebark.htm.

Warncke, D. 1998. Recommended test procedure for greenhouse growth media, p. 34-37. In Dahnke, W.C. (ed.). Recommended chemical soil test procedures for the North Central Region. North Central Reg. Res. Pub. No. 221. Miss. Agr. Expt. Stat. SB 1001.

Yeager, T.H. and J.E. Barrett. 1985. Phosphorous and sulfur leaching from an incubated superphosphate-amended soilless container medium. HortScience 20:671-672.

Yeager, T.H., C.H. Gilliam, T.E. Bilderback, D.C. Fare, A.X. Niemiera, and K.M. Tilt. 2000. Best management practices guide for producing container-grown plants. Southern Nursery Assoc., Atlanta, GA.

Yeager, T.H. and R.D. Wright. 1982. Pine barkphosphorus relationships. Commun. Soil Sci. Plant Anal. 13:57-66. 